УДК 338.465 .4

JEL I23, D81, O14

https://doi.org/10.21122/2309-6667-2021-14-65-70

\title{
A STUDY ON RISK RESPONSE TO PANDEMIC-CAUSED SERVICE PROCESS DISRUPTION IN HIGHER EDUCATION
}

\author{
A. V. Matskevich \\ e.matskevich@hotmail.com \\ Senior lecturer at the Department "Business Administration" \\ School of business of BSU \\ Minsk, Republic of Belarus
}

More than 300 million students worldwide are having their education disrupted by the spread of Coronavirus. As a result, traditional education has been urged to change study approaches quickly and dramatically, with the distinctive rise of online learning. When facing the risk of service process disruption, the main goal of HEI's is to respond in a way to provide "service as usual". Despite of a risk commonality, the strategic paths each school has chosen, the critical incidents it went through in a process, and the insights into the future of traditional education differ from school to school. The choice of the initial emergency responses is being researched in regards to business resilience plans.

Keywords: HEI, online-learning, risk response, risk appetite, business resilience, risk management, process disruption.

Цитирование: Matskevich, A. V. A study on risk response to pandemic-caused service process disruption in higher education / A. V. Matskevich // Экономическая наука сегодня : сб. науч. ст. / БНТУ. - Минск, 2021. - Вып. 14. - С. 65-70. https://doi.org/10.21122/2309-6667-2021-14-65-70

Introduction. «Enterprise risk management is a process, effected by an entity's board of directors, management and other personnel, applied in strategy setting and across the enterprise, designed to identify potential events that may affect the entity, and manage risk to be within its risk appetite, to provide reasonable assurance regarding the achievement of entity objectives» ${ }^{1}$.

«In 2003 the National Association of College and University Business Officers (NACUBO) released a report on risk management in higher education that encouraged HEI's to develop, implement and enhance their risk management programs» [1, p. 4].

Risks in HEI result from two types of sources: an internal cause (within the organization) or an external cause (outside the organization).

Thus, «in higher education risks are assigned to the following three domains:

a. HEI as a microcosm of society (events related to social safety and security)

b. HEI as an organization (events impacting organizational safety and security)

c. HEI as a custodian of knowledge (events impacting the security of knowledge)» [2, p. 144].

Classified by the impact, risks may be of an internal or an external impact. In the case of an internal impact the HEI is the primary owner of the risk. In the case of an external impact managing risk will require consultation with external stakeholders such as, for instance, the authorities. Both types all risk might fall under «pure, speculative or uncertainty types of risk» [3].

In this article, «risk is defined as the likelihood of the event of educational process disruption occurring and the associated impact of the event. Likelihood refers to the probability or potential of the event occurring. Impact refers to process disruption consequences including financial, infrastructural, marketplace and reputational impacts. Risk assessment is a systematic process for gathering, assessing and documenting information to assign a level of risk $\rangle^{2}$. Risk assessment aims to determine the likelihood and impact of events so that action can be taken to manage and reduce the negative con-

\footnotetext{
${ }^{1}$ Enterprise Risk Management - Integrated Framework, Executive Summary. [Electronic resource] // Committee of Sponsoring Organizations of the Treadway Commission. - Mode of access: www.coso.org/documents/COSO_ERM_ExecutiveSummary. pdf. - Date of access: 05.09.2021.

${ }^{2}$ Rapid risk assessment of acute public health events. [Electronic resource] // World Health Organization. - Mode of access: http://apps.who.int/iris/bitstream/10665/70810/1/WHO_HSE_GAR_ARO_2012.1_eng.pdf. - Date of access: 19.09 .2021 .
} 
sequences. The process involves assessment of three components: the hazard, the possible exposure(s) to the hazard, and the context in which the event is occurring. In case with pandemic, the hazard can be identified as virus spread, to which staff and students are being exposed, causing educational process disruption. Context assessment will be different for each organization as it involves evaluation of the environment in which the event takes place with factors of internal and external environment considered. Each organization pursues various strategic value-adding objectives. An organization must consider its risk appetite and risk capacity when choosing their strategy and deciding upon operational tactics. Risk appetite is the amount of risk, on a broad level, an organization is willing to accept in pursuit of value. Risk capacity is the ability to take this risk, both financially and infrastructurally.

The risk assessment process helps identify the most significant risks based on the probability of occurrence and the severity of the impact. The next step in risk management process suggests «the selection of risk response strategy (avoid, transfer, accept, mitigate) and the introduction of loss prevention measures for the risks that can be treated or mitigated» [3]. When there is little ability to control a risk caused by external forces, the focus shifts to the potential impacts of the risk event and what could be done to respond. The choice of a risk response strategy depends on organization's risk appetite and risk capacity.

When talking about risks to HEI process disruption caused by global pandemic of COVID-19, the risk has an external cause, falls under all three of the above-mentioned domains, appears to be both pure and uncertainty risk, is an operational risk to a process (causing process disruption), and has both external and internal impacts. "The multifaceted nature of the event and the magnitude of the impact allow to identify the situation HEI's found themselves in after the announcement of the global pandemic, as a significant risk or a crisis $\gg{ }^{1}$. As mentioned above, HEI as an organization is at loss exposure to the same risks as every organization is. However, in the educational sector, some of them may have a direct impact on the continuity of education and research. Thus, the primary objective of risk management function in HEI is to identify possible significant risks and come up with risk response strategies that will allow for business as usual. In the event of a crisis, a Business Continuity Plan provides guidelines for continuing primary, essential and or critical functions, embedded into a framework and approach for a most effective response to an emergent event. Moreover, BCP suggest a strategy to business resilience and return to «business as usual».

As reported by Pearson, currently «more than 300 million students worldwide are having their education disrupted by the spread of Coronavirus» ${ }^{2}$. The COVID-19 pandemic has disrupted every aspect of university life and both staff and students have had to show tremendous resilience. When first facing this risk, the main goal of HEI was to find new ways that will allow them providing service as usual. Traditional education faced an urgent need to change their study approaches quickly and dramatically, giving the rise to online learning.

According to the latest report on the World Economic Forum, «online learning has been shown to increase retention of information, and take less time, meaning the changes coronavirus have caused might be here to stay» ${ }^{3}$. In HE sector institutions are often quite risk averse in their strategic objectives and thus, too slow to experiment with new learning approaches, such as, for instance, online learning, or other applications of ICT to learning process. However, significant shifts in science and business occur when unexpected events force widespread implementation of an innovative idea. Right now, the Coronavirus pandemic is forcing global experimentation with remote teaching and learning. If distant learning proves to be a success, it will transform traditional education for good.

«All industries are experiencing change and ongoing challenges since the announcement of the COVID-19 pandemic, but the higher education sector is among those that have experienced most sig-

\footnotetext{
${ }^{1}$ Managing risk in higher education: Higher education sector risk profile 2021. [Electronic resource] // PwC Risk. - Mode of access: https://www.pwc.co.uk/government-public-sector/education/documents/highereducation-sector-risk-profile-2021.pdf. - Date of access: 18.09.2021.

2 Continuing education during uncertainty. [Electronic resource] // Pearson education. - Mode of access: https://www.pearson.com/news-and-research/working-learning-online-during-pandemic.html_. - Date of access: 05.09.2021.

${ }^{3}$ The COVID-19 pandemic has changed education forever. This is how. [Electronic resource] // World Economic Forum. - Mode of access: https://www.weforum.org/agenda/2020/04/coronavirus-education-global-covid19online-digital-learning/. - Date of access: 20.09.2021.
} 
nificant business disruption» ${ }^{1}$. In March 2020, universities switched their mode of teaching to distant learning in a matter of days with inevitable impact on both infrastructure and student experience, from closed campuses, students leaving dormitories and returning home, and teaching being moved online. Higher education sector has been gradually moving toward distance learning for years, but COVID-19 has made them go for it overnight. On one hand, HEI's should appreciate the challenge. On the other, any significant risk materializing and causing process disruption is a crisis for an organization.

The fundamental strategic objectives of higher education institutions are still the same: teaching students, preserving academic integrity, complying with state regulations, and achieving financial goals. For most HEI's what has changed is the operational process - from traditional in-class teaching to full-on distant learning. However, not every university adopted the same risk response strategy. Differences arise when looking into approaches not only in different countries, but also among the HEI's in the same country.

Among the reasons behind that are introduction of a lockdown in some countries, but not in the other, technological advances, staff preparedness and BCP approaches. For instance, traditional universities were not as quick to adopt online learning as their OER competitors. However, «traditional or innovative, educational establishments around the world seemed to be quite successful in their responses to a crisis of a global pandemic. Now society is examining the shift to virtual learning resulting from COVID-19, and what the long-term effect of that might be on the higher education sector and wonder whether the return to traditional on-campus classrooms and lectures is necessary» ${ }^{2}$.

Faced with unprecedented challenges in response to the COVID-19 pandemic, Higher Education Institutions (HEIs) adapted quickly and proactively with an unprecedented level of agility. And the main tool that helped HEI's respond to the pandemic rather successfully was them implementing their business continuity management plans.

When responding to educational process disruption caused by global pandemic, HEI's adopted one or more of the following risk response strategies: a) accept: no changes introduced; b) tolerate: introduce safety measures such as wearing masks, checking students and staff for fever; c) transfer: partnerships, insurance; d) mitigate: online learning, blended learning, collaborations.

As both the changes and the pace of them are unprecedented, and uncertainty regarding the future still represents a risk, permanent monitoring of the effectiveness of responses among HEI's is required to allow for development of the most viable business model for business continuity planning.

Results and its discussion. Global pandemic caused disruption in traditional service provision in HEI's worldwide, which led many to pursue different risk response strategies.

The aim of this research is to investigate the risk response strategies different HE's have adopted as their emergency response to pandemic, the advantages and disadvantages of a strategy of choice, and the further plans on business continuity plan for business recovery in case global pandemic persists.

Three hypotheses have been developed:

1. HEI's under the same external environment conditions adopted different approaches to respond to service process disruption caused by global pandemic.

2. Online learning is here to stay, but the approaches to how much of it will be embedded into educational programs differ depending on risk appetite of each particular HEI.

3. Despite the abruptness of the event, and HEI's unpreparedness in response, staff experience with new mode of teaching is overall positive.

The conceptual model has been developed to test the hypothesis (see figure):

\footnotetext{
${ }^{1}$ Kelly, M. (2020) Lessons on COVID-19 risk management in higher education. [Electronic resource] // Galvanize. - Mode of access: https://www.wegalvanize.com/risk/higher-education-covid-19/. - Date of access: 19.09.2021.

${ }^{2}$ Govindarajan, V., Srivastava, A. (2020). What the Shift to Virtual Learning Could Mean for the Future of Higher Ed. [Electronic resource] // Harvard Business Review. - Mode of access: https://hbr.org/2020/03/what-theshift-to-virtual-learning-could-mean-for-the-future-of-higher-ed. - Date of access: 11.09.2021.
} 


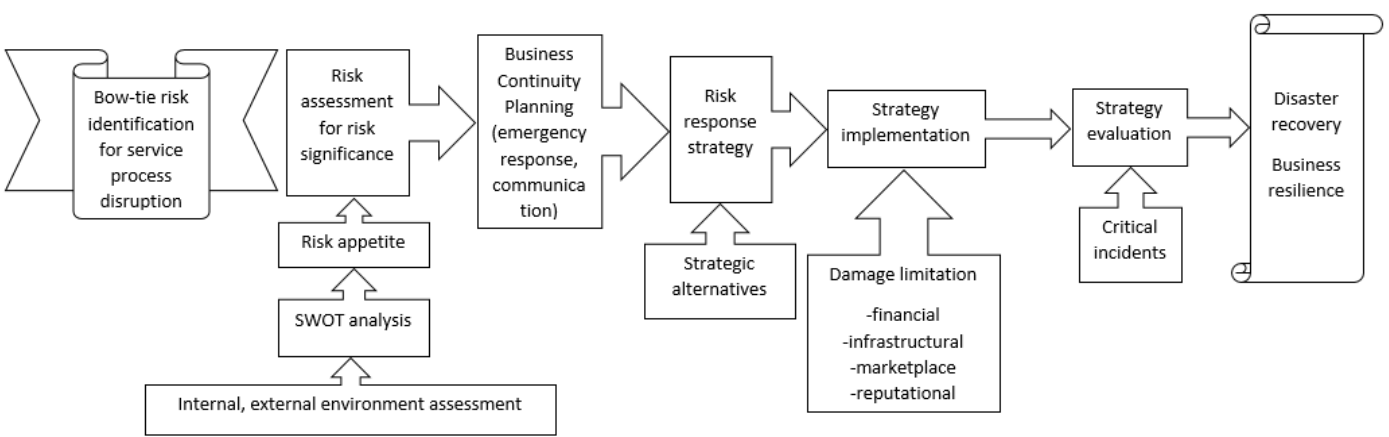

Source: author's own elaboration

Conceptual model

From the conceptual model the following research questions have been identified: countries?

1. What are the risk response strategies to educational process disruption among HEI's in CIS

2. What are the advantages and disadvantages of each strategy of choice?

3. Would academic staff be willing to continue with the current strategy, why/why not?

The purpose of the research was to identify common themes and good practice between HEI's, the lessons learned and positive changes that were caused by the response to a risk event, and reveal whether these benefits will be locked for sustainable longer term change, as the sector is facing ongoing financial and operational challenges. Considering that the situation with global pandemic continues to evolve, particularly regarding national lockdown measures and other restrictions, going forward, HEI's will need to ensure that the risks are managed effectively despite of continuing uncertainty and instability.

The research framework for the risk survey conducted is presented in a form of a conceptual model. The risk survey, developed based on a model, used a structured questionnaire.

The objective of the survey was to reflect on both the opportunities and challenges that COVID-19 has presented a HEI with, identify the main risk response strategy HEI's have decided to adopt, reveal advantages and disadvantages of the choice made from the point of view of academic staff, and collect the expectations of future modes of operation.

The respondents were selected randomly among the academic staff from traditional universities in Belarus, Russia, Ukraine, and Georgia. The questionnaire was distributed by mail in a form of a Word document, along with a link to an online form.

After the first stage in new strategy implementation in response to the risk of service process disruption has past, now is the time to evaluate the first results. One of the most frequently asked questions is whether the adoption of online learning will continue to persist post-pandemic, to which extent, and what will be the best solution on incorporating the newly-acquired online-learning experience into traditional ways for different types of schools when "things go back to normal".

According to survey results, $64 \%$ of HEI's gave up on its original educational strategy to implement a new one at the time of COVID-19 pandemic.

Among those $78,6 \%$ implemented blended learning as their risk response strategy as a mitigation of adverse effect of COVID-19 pandemic, and 21,4\% implemented full online learning. However, $21,4 \%$ still believe that accepting the risk and not trying to manage it would have no impact on academic process. At the same time, more than half of the participants believe that the response was timely and appropriate.

The respondents reported that implemented response strategies allowed for prevention in virus spread, increased computer literacy for both staff and students, as well as provided students with opportunity for self-study and prevented disruption to educational process. However, among the disadvantages of online/blended learning they mentioned lack of communication among teachers and students, boredom, lack of technology to support workshops, lack of staff preparedness to teaching remotely, pitfalls in process organization. It's interesting to note, that only $35,7 \%$ of the respondents reported that their HEI was prepared for the challenge, whereas 21,4\% believe that it was not, and $42,9 \%$ are not sure about it. The later makes one think that whatever BCP was implemented, it was not communicated to the staff. 
Only $42,9 \%$ of the participants noted that their HEI is still following first response strategy, but $70 \%$ of them still consider the level of risk of educational process disruption to be significant. It is important to emphasize, that based on survey results over half of the respondents would prefer if their HEI goes "back to normal (traditional)" mode of teaching after the pandemic is over, and then 35,7 \% are still not sure about their preferences. The main reason behind it are issues with organization of the distant learning process, such as difficulties with scheduling, the need for students' physical presence for some of the classes, need for control over learning results. However, if the HEI decides to never return to old ways, $90 \%$ said they'd prefer blended learning as their permanent mode of teaching. Among the reasons behind them not willing to work fully remotely are lack of communication between teachers and students, lack of control over learning process, difficulties with performing group activities remotely.

Conclusion. Despite of relative effectiveness of first response strategies, HEI's still need to consider their approaches to manage the prolonged impact of the COVID-19 pandemic situation as it is still unfolding. The HEI's need to continue to reflect on lessons learnt from their first risk response to the pandemic and ensure continuous improvement of their BCM capability by conducting interviews and group discussions with both academic staff and students, as their perceptions of the effectiveness of the implemented measures to mitigate the risk might differ. If making a decision to change the strategy, the HEI needs to take into account the benefits derived from the experience and embed them into organization long-term. If the HEI decides to continue with online/blended learning postpandemic, the disadvantages should be taken into consideration, with lack of communication being one of the most significant, and need for more advanced technology introduced being the second most quoted.

\title{
References
}

1. Cassidy, D. et. al (2003) Developing a Strategy to Manage Enterprisewide Risk in Higher Education. $N A C U B O, 4-7$.

2. Helsloot, I., Jong, W. (2006) Risk Management in Higher Education and Research in the Netherlands. Journal of Contingencies and Crisis Management. 14(3), 142-159.

3. Hillson, D. (2001) Effective strategies for exploiting opportunities. Paper presented at Project Management Institute Annual Seminars \& Symposium, Nashville, TN. Newtown Square, PA: Project Management Institute.

Статья поступила в редакиию 7 октября 2021 года

\section{ИССЛЕДОВАНИЕ РЕАКЦИИ ВЫСШЕГО ОБРАЗОВАНИЯ НА РИСК НАРУШЕНИЯ ПРОЦЕССА ПРЕДОСТАВЛЕНИЯ УСЛУГИ В СВЯЗИ С ПАНДЕМИЕЙ}

Е. В. Мацкевич

Старший преподаватель кафедры «Бизнес-администрирование»

Институт бизнеса БГУ

г. Минск, Республика Беларусь

\begin{abstract}
В мире более 300 миллионов студентов пострадали из-за нарушения учебного прочесса в связи с распространением Ковид-19. В результате традиционное высшее образование вынуждено было срочно менять подходы к прочессу обучения, зачастую отдав предпочтение онлайнобразованию. Столкнувшись с риском нарушения процесса оказания услуг, основной целью ВУЗов стал выбор наиболее эффективной стратегии реакции на риск, которая позволила бы предоставлять «услугу, как обычно». Несмотря на общность риска, каждый вуз выбирал свою собственную стратегию реагирования. В результате критические инциденты, произошедшие впоследствии этого выбора, и представления о будущем традиционного образования для каждого вуза свои. В статье исследуются варианты мер реагирования на риск и их взаимосвязь с обеспечением устойчивости процесса предоставления услуг в высшем образовании.
\end{abstract}

Ключевые слова: учреждения высшего образования, онлайн обучение, реакция на риск, аппетит к риску, устойчивость бизнеса, управление рисками, сбой процесса. 


\section{Список использованных источников}

1. Cassidy, D. et. al. Developing a Strategy to Manage Enterprisewide Risk in Higher Education / D. Cassidy et al. // NACUBO. - 2003. - P. 4-7.

2. Helsloot, I. Risk Management in Higher Education and Research in the Netherlands / I. Helsloot, W. Jong // Journal of Contingencies and Crisis Management. - 2006. - Vol. 14, № 3. P. 142-159.

3. Hillson, D. Effective strategies for exploiting opportunities / D. Hillson // Paper presented at Project Management Institute Annual Seminars \& Symposium, Nashville, TN. Newtown Square, PA: Project Management Institute. - 2001. 